\title{
Scaled model tests on influence factors of full geosynthetic-reinforced pile-supported embankments
}

\author{
C. $\mathrm{Xu}^{1}, \mathrm{~S}$. Song ${ }^{2}$ and J. $\mathrm{Han}^{3}$ \\ ${ }^{1}$ Professor, Key Laboratory of Geotechnical and Underground Engineering of Ministry of Education, \\ Tongji University, Shanghai, China, Telephone: +86 21 65987079; Telefax: +86 21 65987079; \\ E-mail: c_axu@tongji.edu.cn (corresponding author) \\ ${ }^{2}$ PhD Student, Department of Geotechnical Engineering, Tongji University, Shanghai, China, \\ Telephone: +8621 65987079; Telefax: +8621 65987079; E-mail: stone1105@foxmail.com \\ ${ }^{3}$ Professor, Department of Civil, Environmental, and Architectural Engineering, The University of Kansas, \\ Lawrence, KS, USA, Telephone: +01 785864 3714; Telefax:+01 785864 5631; E-mail: jiehan@ku.edu
}

Received 17 May 2015, revised 3 September 2015, accepted 9 September 2015, published 25 November 2015

\begin{abstract}
A geosynthetic-reinforced pile-supported (GRPS) embankment that consists of embankment fill, geosynthetic, piles, and foundation soils is a complex soil-structure system. Its key load transfer mechanisms include soil arching and tensioned membrane effects and subsoil resistance. Type of embankment fill (cohesive or cohesionless) and type of pile (end-bearing or floating) are expected to affect these load transfer mechanisms; however, their influence has not been well investigated. Six scaled model tests were conducted in this study to investigate the influence of the embankment fill properties, the clear spacing of pile caps, and the pile type on soil arching and tensioned membrane effects. This study used cohesive and cohesionless embankment fills and end-bearing and floating piles. The test results show that the cohesive embankment fill strengthened the soil-arching effect, increased the pile efficacy, and reduced the settlements of the subsoil between pile caps and the embankment crest under the same load as compared with the cohesionless embankment fill. The soil arching-effect was inversely proportional to the clear spacing of pile caps. Soil arching initiated at a low ratio of the embankment height to the clear spacing of pile caps (i.e. 0.5 to 0.7 ) and became stable at a higher ratio (i.e. 1.1 to 1.5). The embankment height when the soil arching becomes stable is also referred to as the critical height, at which full soil arching is formed. The measured vertical earth pressures at the edges of the pile caps were higher than those in the middle of the pile caps in all six model tests. When the end-bearing or floating piles were used, the loads on the piles (i.e. the pile efficacy) increased during the construction of the embankment. However, when the floating piles started to penetrate into the underlying soil under a higher load; the pile efficacy decreased with the embankment and the surcharge load. Floating piles resulted in less soil arching and larger settlement.
\end{abstract}

KEYWORDS: Geosynthetics, Earth pressure, Embankment, Pile, Settlement, Soil arching, Tensioned membrane

REFERENCE: Xu, C., Song, S. and Han, J. (2016). Scaled model tests on influence factors of full geosynthetic-reinforced pile-supported embankments. Geosynthetics International, 23, No. 2, 140-153. [http://dx.doi.org/10.1680/jgein.15.00038]

\section{INTRODUCTION}

Embankments have been increasingly used to support highways and railways; however, the number of sites with suitable soil conditions has decreased. As a result, more and more embankments have been constructed on land that was previously considered unsuitable. Sowers (1979) defined that soft clay has an undrained shear strength that is lower than $25 \mathrm{kPa}$. Construction of embankments on soft foundations often encounters possible bearing failure, excessive settlement, and slope instability. Construction time and time to settlement stabilisation are also important challenges to construction over soft foundations. Certain techniques must be used to improve the soil foundation to enhance the stability of the embankment and eliminate the problems associated with bearing failure and settlement (Han and Gabr 2002; Jenck et al. 2007; Han 2015b). Possible techniques include surface and deep compaction and densification, over-excavation and replacement, deep replacement, preloading and consolidation, and chemical stabilisation (Han 2015a). However, granular columns (including geosyntheticencased granular columns), deep mixed columns, and piles have been more commonly used to support 
embankments over soft soils (Han 2015a, 2015b). When approaching embankments are used to connect bridges or new embankments are constructed to widen existing embankments, there is a strict requirement for total and differential settlements on top of the embankment (often less than $25 \mathrm{~mm}$ ) (Han et al. 2007; El Kamash and Han 2014). To meet such a strict requirement, piles or columns are used to support the embankments. In comparison with some other ground improvement methods, geosynthetic-reinforced pile-supported (GRPS) embankments can be constructed quickly, do not require soft soil replacement and staged construction, and meet strict settlement requirements; therefore, they become one of the favoured technologies for the construction of embankments on soft soil foundations.

A GRPS embankment, consisting of a soft soil foundation, piles, a geosynthetic-reinforced platform (or mattress), and embankment fill, is a complex soilstructure system. The interaction among these components influences the load distribution and the functions of the reinforcement. The key mechanisms of GRPS embankments have been considered to be soil arching, the tensioned membrane effect, and stress concentration due to modulus difference between piles and soil (Han, 1999; Han and Gabr 2002). Han (1999) and Han and Gabr (2002) defined soil arching as the phenomenon that differential movement between piles and subsoil induces shear stresses in the fill, which transfer a large portion of the vertical loads to piles and reduce the vertical stresses on the subsoil between these piles. The tensioned membrane effect is referred to as the deformed geosynthetic reinforcement between the piles reducing the vertical stresses on the subsoil below the reinforcement by its vertical component of the tension in the reinforcement. When a rigid platform (e.g. footing) is above piles and subsoil, there are no soil arching and tensioned membrane effect because there is no differential movement but there is still stress concentration on the piles due to their modulus difference between piles and soil. However, several factors, including the properties of embankment fill, the height of the embankment, the size and layout of the piles (or pile caps), the properties of soft soil, and the properties and number of geosynthetics, play important roles in the performance of GRPS embankments. Piles used in GRPS embankments are mostly end-bearing but some embankments are supported by floating piles (Chen et al. 2008a). When piles and/or large pile spacing are used, pile caps are often needed to reduce the clear spacing between piles and the differential settlement on top of the embankment.

Many researchers have carried out experimental studies on pile-supported embankments in the past. Most of them used dry or moist sand as the embankment fill, whereas Horgan and Sarsby (2002) used sand and stone in their tests. Jenck et al. (2009) used a mix of steel rods, $60 \mathrm{~mm}$ long with diameters of 3-5 mm. van Eekelen et al. (2012) used a crushed recycled construction material. Few researchers used soil with cohesion as the embankment fill. For example, Miao et al. (2013) used a cement-treated sand-expanded polystyrene (EPS) bead lightweight material as an embankment fill. This study introduced an 'apparent cohesion' for the embankment fill to illustrate the influence of embankment fill properties on soil arching and tensioned membrane effects.

To simulate subsoil settlement between piles, several researchers removed subsoil support during the test, either by a 'trap door' (Horgan and Sarsby 2002), or direct removal (Le Hello 2007). Some others used a compressible material to represent subsoil, such as peat (Zaeske 2001; Heitz 2006; Farag 2008), rubber foam (Low et al. 1994; van Eekelen et al. 2003; Jenck et al. 2009), or rubber foam chips (Hewlett and Randolph 1988). Ellis and Aslam (2009a, 2009b) varied the stiffness of the subsoil by using two grades of EPS in their centrifuge tests. Chen et al. (2008b) and Miao et al. (2014) modelled the consolidation of the subsoil in their tests by gradually draining water out from water bags. Only a few (such as Zaeske 2001; Heitz 2006; Le Hello 2007, Chen et al. 2008b, and van Eekelen et al. 2012) included geosynthetic reinforcement.

In the above studies, Farag (2008) measured the forces on or below the piles, whereas Zaeske (2001) and Heitz (2006) measured the pressures within the fill. van Eekelen et al. (2012) measured the earth pressure on and below the geosynthetic reinforcement. All the above studies found the soil arching effect. Heitz (2006) found that the soil arch was resistant to some dynamic load if sufficient reinforcement was used. To the authors' knowledge, however, no experimental study has been reported with embankments supported by floating piles. This study investigated the performance of geosynthetic-reinforced floating pilesupported embankments and the effect of this pile type.

This study included six scaled model tests of full GRPS embankments conducted in a large test box in a laboratory of Tongji University. Unlike some earlier studies in which only a unit cell of a GRPS embankment or an embankment without any slope supported by four piles (e.g. Zaeske 2001; van Eekelen et al. 2012) was investigated, this study employed a scaled full embankment model with side slopes on piles with pile caps subjected to a vertical load and investigated the influences of the embankment fill (fine sand or fine sand mixed with fibres), the clear spacing of pile caps, and the pile type on the soil-arching effect and the tensioned membrane effect.

\section{MODEL TESTS}

\subsection{Test setup}

Figure 1 shows the test setup of a scaled GRPS embankment under a vertical load. The test box, made of structural steel and toughened glass, was $3.0 \mathrm{~m}$ long, $1.0 \mathrm{~m}$ wide, and $1.8 \mathrm{~m}$ high. Figure 1a shows the GRPS embankment with end-bearing piles and pile caps and Figure $1 \mathrm{~b}$ shows that with floating piles and pile caps. Figure 1c is a top view of the GRPS embankment with ten pile caps (partially exposed).

\subsection{Materials}

Fine sand was used to form the subsoil foundation and construct the embankment. Figure 2 shows the gradation 


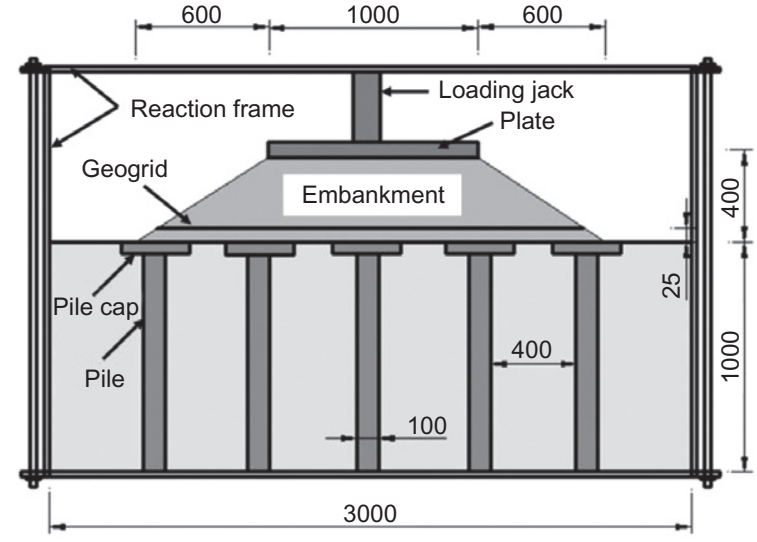

(a)

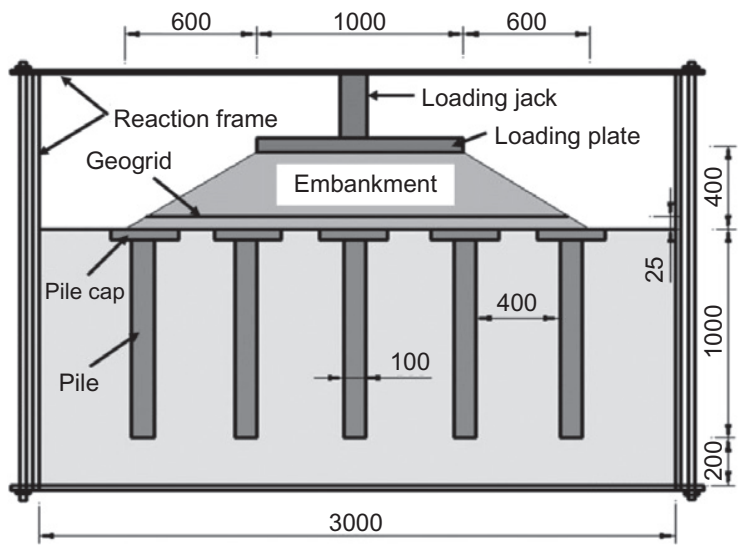

(b)

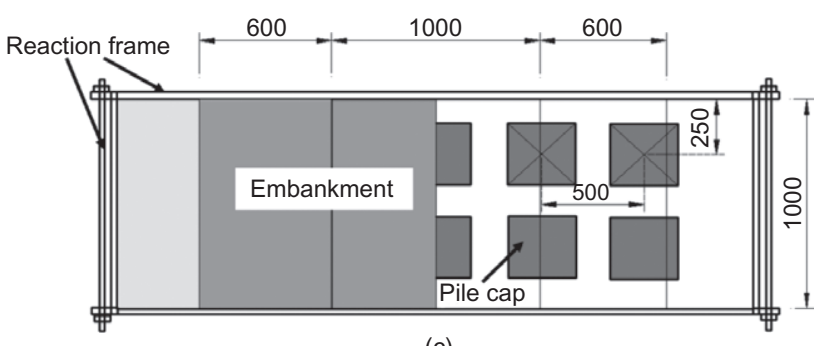

(c)

Figure 1. Cross-sectional and top views of GRPS embankments: (a) cross-section of the model with end bearing piles,

(b) cross-section of the model with floating piles, (c) top view of the model (unit: mm)

of the fine sand, which had a uniformity coefficient of 2.73 and a curvature coefficient of 0.51 ; therefore, the sand was poorly-graded based on the Unified Soil Classification System (ASTM D2487-11). This sand had the maximum dry density of $1.99 \mathrm{~g} / \mathrm{mm}^{3}$ based on the standard Proctor compaction tests. The sand was mixed with $5 \%$ (dry mass of sand) EPS beads with a diameter of 3-4 mm to simulate a compressible subsoil. The maximum dry density of the sand-EPS mixture was $1.91 \mathrm{~g} / \mathrm{mm}^{3}$ based on the standard Proctor compaction tests. Laboratory triaxial tests measured the peak friction angle of the subsoil at $90 \%$ relative compaction was $27^{\circ}$ and laboratory consolidation tests determined its constrained modulus at 3.74-4.41 MPa.

Two embankments fills, fine sand and sand-fibre mixture, were used in this study. Laboratory triaxial tests showed that the peak friction angle of the fine sand was

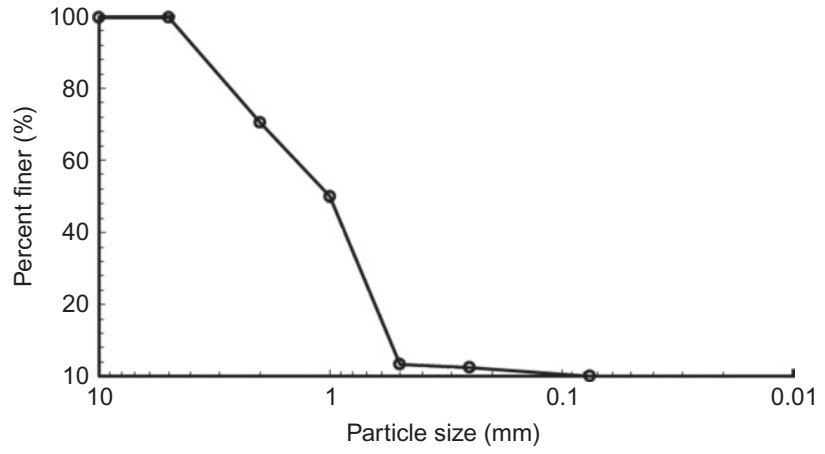

Figure 2. Gradation curve of sand in the tests

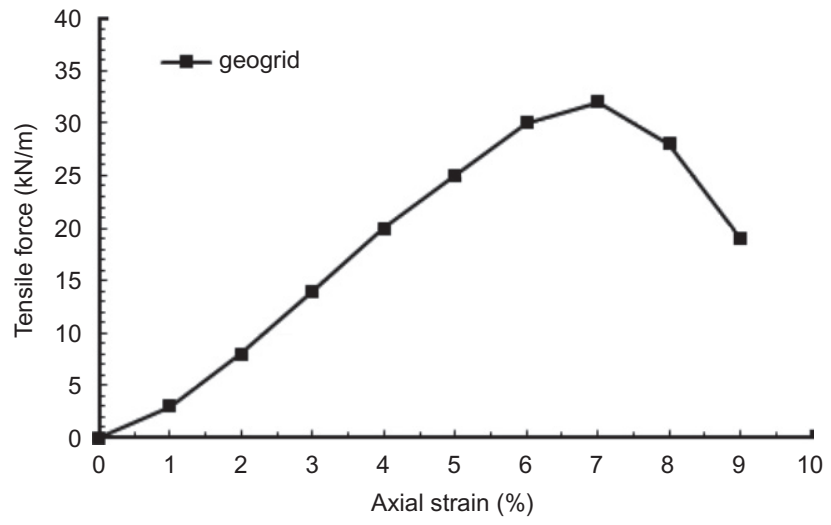

Figure 3. Curve of tensile force against axial strain of the geogrid

$38^{\circ}$. To investigate the influence of fill cohesion on the soil-arching effect and the tensioned membrane effect, a mixture of sand and fibres was employed to simulate the embankment fill with cohesion. The sand-fibre mixture contained $0.3 \%$ (dry mass of sand) fibres with lengths of $30-40 \mathrm{~mm}$. The maximum dry density of the sand-fibre mixture was $1.98 \mathrm{~g} / \mathrm{mm}^{3}$ based on the standard Proctor compaction tests. Laboratory triaxial tests determined a peak friction angle of $38^{\circ}$ and an apparent cohesion of $15 \mathrm{kPa}$ for the sand-fibre mixture at $90 \%$ relative compaction. From triaxial tests, the modulus of the fibrereinforced sand was estimated to be approximately 1.25 times that of the sand.

The geosynthetic reinforcement was biaxial PP geogrid with an aperture size of $40 \mathrm{~mm} \times 40 \mathrm{~mm}$. Figure 3 shows the curve of tensile force plotted against axial strain of the geosynthetic reinforcement, which had an ultimate tensile strength of $32 \mathrm{kN} / \mathrm{m}$ and a tensile stiffness of $500 \mathrm{kN} / \mathrm{m}$ at a tensile strain of $5 \%$. The tensile test of the geogrid was conducted over a short term at the displacement rate of $100 \mathrm{~mm} / \mathrm{min}$. The piles were made of plain concrete with a diameter of $100 \mathrm{~mm}$ and a length of $1 \mathrm{~m}$. The pile caps were made of square steel plates of three different sizes: $120 \mathrm{~mm} \times 120 \mathrm{~mm}, 240 \mathrm{~mm} \times 240 \mathrm{~mm}$, and $300 \mathrm{~mm} \times 300 \mathrm{~mm}$. The pile caps were fastened onto the piles in the model tests.

\subsection{Test sections}

Table 1 lists six model tests carried out in this study, which include the embankment fill type, the width of the square 
Table 1. Test programme of GRPS embankments

\begin{tabular}{|l|l|c|c|l|}
\hline $\begin{array}{l}\text { Number of } \\
\text { model test }\end{array}$ & Fill type & $a(\mathrm{~mm})$ & $h /(s-a)$ & Pile type \\
\hline 1 & Sand & 300 & 2.0 & End bearing \\
2 & Sand with fibre & 300 & 2.0 & End bearing \\
3 & Sand with fibre & 240 & 1.5 & End bearing \\
4 & Sand with fibre & 120 & 1.1 & End bearing \\
5 & Sand with fibre & 300 & 2.0 & Floating \\
6 & Sand with fibre & 240 & 1.5 & Floating \\
\hline
\end{tabular}

pile cap (a), the ratio of the embankment height to the clear spacing of the pile caps $[h /(s-a)]$, and the pile type. Test 1 used the sand as the embankment fill. Tests 2 to 6 used the sand-fibre mixture as the embankment fill. End bearing piles were used in tests 1 to 4 and floating piles were used in tests 5 and 6 .

\subsection{Construction}

Two types of piles, end-bearing piles and floating piles were used in this study. Depending on the type of piles, the construction of the test section was slightly different. For the test section with end-bearing piles, ten piles were placed first and the fine sand mixed with EPS beads was placed in 10 lifts around the piles as shown in Figure 1a. The compacted lift thickness was approximately $100 \mathrm{~mm}$. The subsoil was placed and compacted into the model box using a mass-volume control method. Each lift had a mass of $502.4 \mathrm{~kg}$, which resulted in the average density of subsoil at $1.72 \mathrm{~g} / \mathrm{mm}^{3}$ and the degree of compaction at about $90 \%$.

For the test section with floating piles, the $200 \mathrm{~mm}$ thick bottom fine sand with EPS beads was placed in two lifts (i.e. $100 \mathrm{~mm}$ thick each lift) first, then ten floating piles were installed and followed with the placement of the surrounding fine sand mixed with EPS beads in the same way as described above as shown in Figure $1 \mathrm{~b}$.

Caps were connected with piles. Depending on the type of embankment fill, a $25 \mathrm{~mm}$ thick sand layer (or sand mixed with fibres) was placed on top of the subsoil and pile caps. The geosynthetic reinforcement was placed at $25 \mathrm{~mm}$ above the pile caps to prevent possible damage to the geosynthetic reinforcement by the caps. This soil layer between the geosynthetic reinforcement and the pile caps is commonly used in practice (e.g. Huang et al. 2005). The $400 \mathrm{~mm}$ high embankment was constructed in lifts using the sand (or the sand-fibre mixture). The embankment construction used the similar method as the subsoil placement. When the sand was used as the embankment fill, the embankment was divided into four layers, which had masses of $367.4,313.6,259.8$ and $206.1 \mathrm{~kg}$, respectively, from the bottom to the top due to the change of the geometry. The average density of the sand fill was $1.79 \mathrm{~g} / \mathrm{mm}^{3}$ and the degree of compaction was about $90 \%$. When the sand-fibre mixture was used as the embankment fill, the four compacted layers had masses of 364.5, 311.2, 257.8 and $204.5 \mathrm{~kg}$, respectively, from the bottom to the top of the embankment. The average density of the sand-fibre

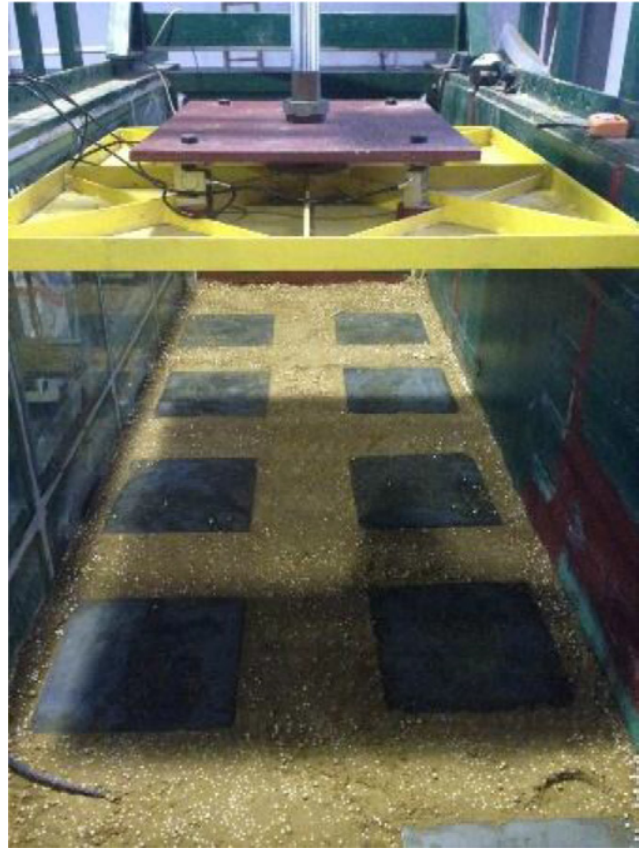

Figure 4. Pile cap layout and the loading plate

mixture was $1.78 \mathrm{~g} / \mathrm{mm}^{3}$ and the degree of compaction was about $90 \%$.

The top load was applied by a hydraulic jack on a loading plate with dimensions of $1.0 \mathrm{~m}$ long and $0.97 \mathrm{~m}$ wide. Figure 4 shows the layout of the pile caps and the loading plate.

\subsection{Instrumentation}

Figure 5 presents the instrumentation layout. The displacement transducers and dial gauges were used to monitor the deformations of the embankment while the earth pressure cells were used to monitor the vertical earth pressure distribution.

In the tests, S1 and S2 denote dial gauges used to measure the total settlements on top of the embankment. S1 was located at the centre of the embankment and S2 was located at the shoulder of the embankment. ss1 and ss2 are the displacement transducers connected to the settlement plates to measure the settlements of the subsoil between the pile caps. The displacement transducers ss1 and ss 2 had an accuracy of $0.01 \mathrm{~mm}$. ss 1 was located at the centre of a unit of four pile caps and ss 2 was located at the centre of two adjacent pile caps. sp1 is the displacement transducer (only used in tests 5 and 6), which was located at the edge of the pile cap to measure the settlements of the pile caps. epc 3 to 5 are the earth pressure cells to measure the vertical earth pressures under the embankment and on the subsoil. epc1 to 3 were located at the centre of a unit of four piles above the subsoil. epc1 was at $100 \mathrm{~mm}$ and epc2 was at $50 \mathrm{~mm}$ above the top of subsoil. epc3 was on the top of the subsoil beneath the geosynthetic reinforcement. epc4 was located in the centre and on the top of the pile cap beneath the geosynthetic reinforcement. epc5 was located at the edge and on the top of the pile cap beneath the geosynthetic-reinforcement. 


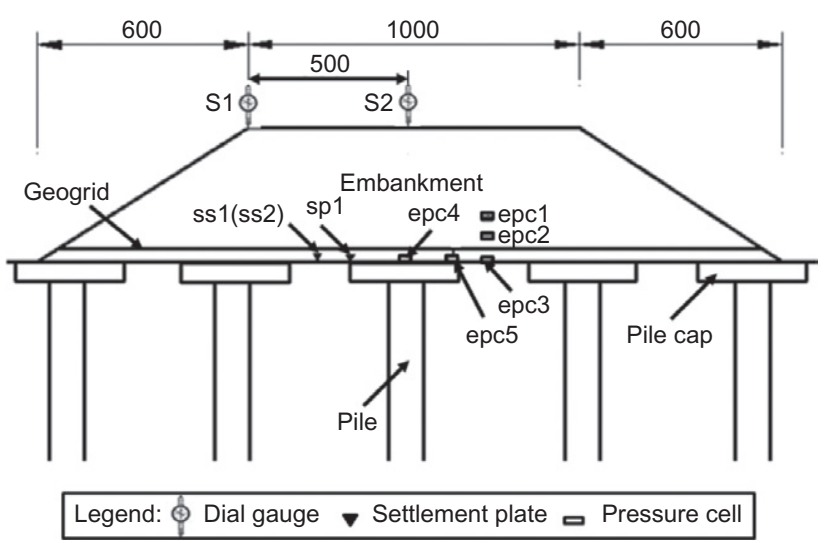

(a)

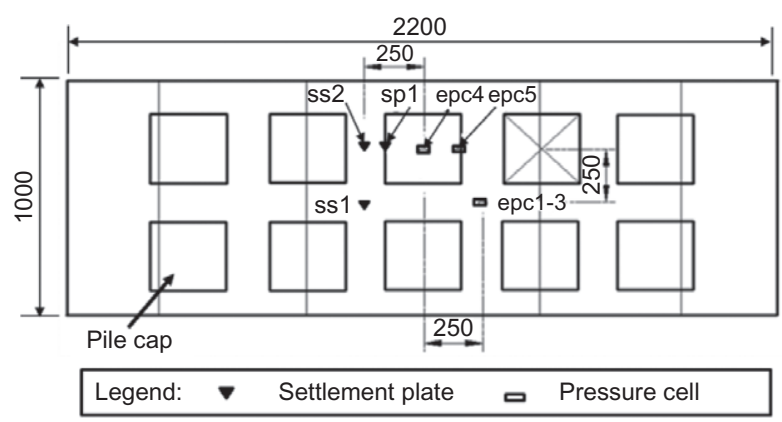

(b)

Figure 5. Instrumentation layout: (a) cross-section, (b) top view (unit: mm)

The number of transducers and their exact locations were the same for all tests, except for those in tests 5 and 6 .

\subsection{Loading procedure}

After the subsoil and the embankment were in place, the following steps were followed for each test: (1) applying the top load in ten increments (an average pressure of $2 \mathrm{kPa}$ for each increment), which represent both the traffic load and the dead weight of a pavement; (2) maintaining each load increment for at least 30 min until stable displacement measurements; however, this is not an indication that the geogrid stopped creeping because a much longer time period would be required to investigate the creep behaviour of the geogrid; (3) recording the displacements by the displacement transducers (ss1, ss2, and sp1) and the dial gauges (S1 and S2); and (4) continuing loading until the maximum average applied pressure reached $20 \mathrm{kPa}$. The applied pressure simulated traffic loading. In the United States, the typical traffic loading used in design is $13 \mathrm{kPa}$ whereas $20 \mathrm{kPa}$ is commonly used in the Chinese specifications or codes for road design. The earth pressure cells (epc1 to 5) were recorded by a computer continuously during the construction of the embankment and loading. Figure 6 shows the loading scheme.

\subsection{Limitations}

This research was conducted in a scaled test box in the laboratory. Some of the conditions may be different from

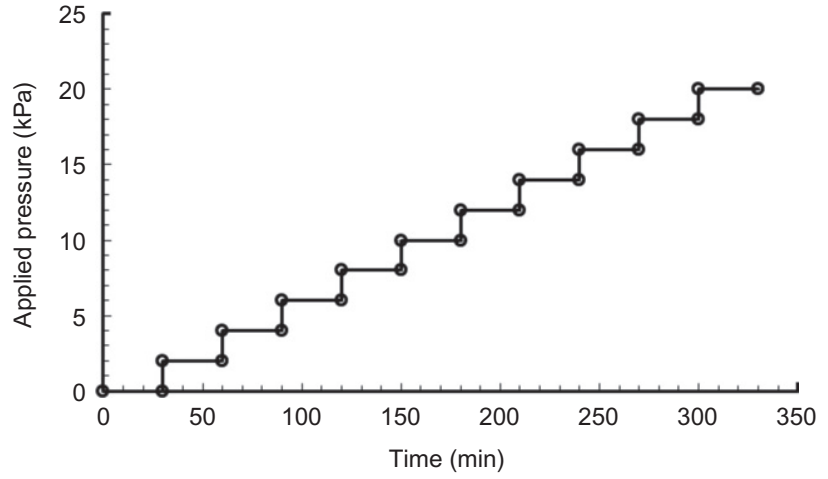

Figure 6. Loading procedure of the tests

those in the field; therefore, this study has the following limitations.

(1) Due to the limited width of the box, the lateral movement of the subsoil was limited by the box walls. Therefore, the instrumentation and data analysis were mostly focused on the central portion of the embankment and the subsoil.

(2) Each test was carried out within a time frame of one week; therefore, this study did not consider the soil consolidation process and other time-dependent effects, such as creep of the geogrid.

(3) GRPS embankment models were designed based on a scale factor of $1 / 5$ to a typical field embankment. The dimensions of the embankment, the piles and the pile caps, and the pile spacing, and the tensile stiffness and strength of the geogrid were scaled down by $1 / 5$. The area and force were scaled down by $1 / 25$.

(4) The side wall friction might reduce the earth pressures measured by pressure cells. As the embankment height was relatively small, the influence of the side wall friction should not be significant, especially under the top load.

(5) Earth pressures on the pile caps and between the pile caps might not be uniform. When the measured earth pressures at specific locations were used to calculate the loads carried by the pile caps and the subsoil, the calculated loads were approximate.

\section{TEST RESULTS AND ANALYSIS}

\subsection{Load distribution}

The total vertical load (i.e. the sum of the traffic load and the pavement and fill weights) is distributed into three parts, A, B, and C according to van Eekelen et al. (2012), in which part A is the load transferred directly to the piles by soil arching, part B is the load transferred from the geosynthetic reinforcement to the piles by the tensioned membrane effect, and part $\mathrm{C}$ is the load carried by the subsoil. All three parts of loads are vertical loads.

Hewlett and Randolph (1988) defined pile efficacy, $E_{\mathrm{p}}$, as a ratio of the vertical force on the pile cap to the total vertical force on the tributary area by one pile, but they did not include a geosynthetic reinforcement in their study. In 
our opinion, soil arching should be defined above the geosynthetic reinforcement. The earth pressure cell above the geosynthetic reinforcement on the pile cap (i.e. part A) is valuable for the soil-arching evaluation, but unfortunately it was not used in this study. Han and Gabr (2002) used a term 'soil-arching ratio' defined based on the earth pressures above the geosynthetic reinforcement to evaluate the soil arching. On the other hand, the pile efficacy should be defined above the pile caps and below the geosynthetic reinforcement if it exists because the pile efficacy is used to evaluate the pile contribution in load carrying. In other words, the vertical force on the pile caps should include the vertical force by soil arching and by the geosynthetic reinforcement (i.e. part $\mathrm{A}+$ part B) if a geosynthetic reinforcement is used. According to this definition, the pile efficacy, $E_{\mathrm{p}}$, can be expressed as follows:

$$
E_{\mathrm{p}}=\frac{a^{2}(\mathrm{ep} 4+\mathrm{ep} 5) / 2}{\left(s^{2}-a^{2}\right) \operatorname{ep} 3+a^{2}(\mathrm{ep} 4+\mathrm{ep} 5) / 2}
$$

where $\mathrm{ep}_{3}$ is the vertical earth pressure measured by pressure cell epc3, ep 4 is the vertical earth pressure measured by epc4, ep $\mathrm{p}_{5}$ is the vertical earth pressure measured by epc5, $a$ is the width of a pile cap, and $s$ is the centre-to-centre spacing of piles.

\subsection{Test results of the baseline model test}

Model test 1 serves as the baseline test, which had the sand as the embankment fill, end-bearing piles, and the $h /(s-a)$ ratio of 2.0 as shown in Table 1 . This section presents the results of the baseline model test including the load distribution and the settlement.

\subsubsection{Earth pressure and pile efficacy}

Figure 7 shows the measured vertical earth pressures from the earth pressure cells, epc1 to 5, during the embankment construction and the loading process in model test 1 . Based on the measured pressures, the pile efficacy was calculated according to Equation 1. Figure 7a shows that the vertical earth pressures at all locations increased with the increase of the embankment height. At the end of the embankment construction, the vertical earth pressure measured by epc1 was higher than that measured by epc 2 whereas the vertical pressure measured by epc 2 was higher than that measured by epc3. The reason for epc1 to have a higher vertical stress than epc 2 can be explained using the concentric soil-arching model proposed by van Eekelen et al. (2013) and van Eekelen (2015). In their model, soil arching is formed in a series of concentric semi-circular domes. Within each layer of a concentric semi-circular dome, the load applied on the upper dome is transferred onto piles and the lower dome. In other words, the vertical stress epl was distributed into two parts: one transferred to pile caps and the other transferred to the lower layer of the dome. Therefore, ep2 at the lower elevation was lower than ep1 at the higher elevation.

However, the vertical pressure measured by epc 4 was lower than that measured by epc5. These measured pressures indicate the vertical stress at the edge of the pile cap was higher than that in the centre of the pile caps.

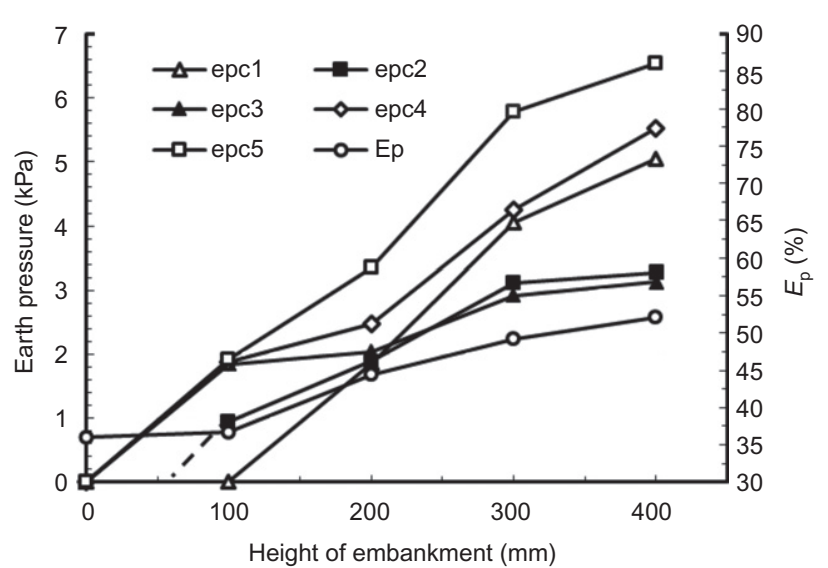

(a)

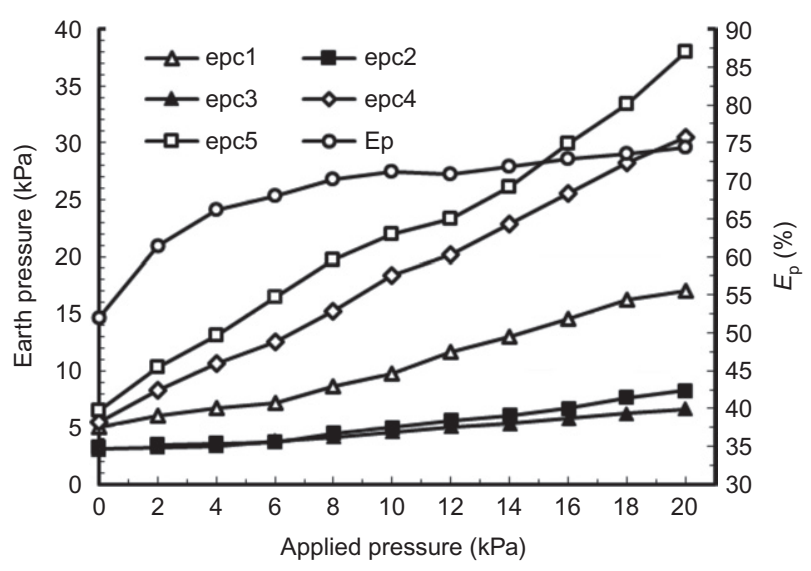

(b)

Figure 7. Measured earth pressures and calculated pile efficacy for model test 1: (a) during construction, (b) during loading

Through a numerical analysis, Han and Gabr (2002) first discovered that the vertical stress at the edge of a pile cap under a geosynthetic reinforcement was higher than that in the centre of the pile cap. The experimental result obtained in this study (i.e. ep5 was higher than ep4) is in agreement with that obtained by Han and Gabr (2002). The main reason for the cap edge to have a higher stress is that the tensioned geogrid transferred part of the load to the pile caps non-uniformly (i.e. more load was transferred onto the edge of pile caps).

The pressure under the geogrid, measured by epc3, was not zero but it was lower than that above the geogrid. These results are in agreement with those obtained by Han and Gabr (2002) and van Eekelen et al. (2012). In other words, the tensioned membrane effect of the geogrid reduced the earth pressure under the geogrid but at the same time, part of the load was transferred to the subsoil.

Figure $7 \mathrm{a}$ shows that before the embankment height reached $100 \mathrm{~mm}$, the earth pressures both above and between the pile caps at the same elevation (i.e. earth pressure cells epc3 to 5) were identical and increased linearly with the height of the embankment. However, when the embankment height was greater than $100 \mathrm{~mm}$, the earth pressure between the pile caps (i.e. ep3) became lower than the earth pressures on the pile caps (i.e. ep4 and 
ep5). Figure 7a also shows that before the embankment height reached $100 \mathrm{~mm}, E_{\mathrm{p}} \approx 36 \%$, which equals to the area coverage ratio of the pile caps. With the increase of the embankment height, $E_{\mathrm{p}}$ increased but at a reduced rate. This result reveals that soil arching was gradually mobilised with the increase of the embankment height.

Figure $7 \mathrm{~b}$ depicts the variation of the vertical earth pressures during the loading process on top of the embankment. The measured results show that the pressures increased linearly with the applied load. The similar relationships among the earth pressures from epc 1 to epc5 remained; that is, the earth pressures decreased in the following order: ep5, ep4, ep1, ep2 and ep3. As compared with the increase of the top load, the increase of $E_{\mathrm{p}}$ was slow after the applied pressure was $6 \mathrm{kPa}$ or higher. This result is in agreement with the model test results of Hewlett and Randolph (1988) and Zaeske (2001). This result also indicates that the soil-arching effect became more significant but in a reduced rate and became stable after the applied pressure was $6 \mathrm{kPa}$ or higher, while the tensioned membrane effect began to transfer more load on the pile caps.

At the full embankment height, the ratio of the embankment height $(h)$ to the clear spacing of the pile caps $(s-a)$ was 2.0, which meets the condition for full arching (BS8006 (BSI 2010)). Figure 7b shows that an increase of the top load increased the vertical earth pressures above the pile caps linearly but the earth pressure between the pile caps just increased slightly. In other words, most of the applied load was transferred to the pile caps due to soil arching and the tensioned membrane of the geogrid but a small portion of the load was transferred to the subsoil between the pile caps. This result is different from the assumption in BS8006 (BSI 2010), in which all the applied top load is transferred to the pile caps under a full soil-arching condition.

\subsubsection{Settlement}

Figure 8 shows the settlements measured by displacement transducers ss 1 and ss 2 in model test 1 during construction and loading. When the embankment height was less than $100 \mathrm{~mm}$, the settlements at ss1 and ss2 were almost identical. When the embankment height was increased from the beginning, the settlement at ss1 continued increasing approximately linearly at a rate of $1.85 \times 10^{-2}$ with the embankment height until the embankment height reached $200 \mathrm{~mm}$ while the settlement across ss2 increased at a slow rate of $0.47 \times 10^{-2}$. As a result, the settlement at ss1 became larger than that at ss2. One reason for this result is because the clear span across ss2 was smaller than the diagonal distance across ss1. The linear increase of the settlement with the embankment height was consistent with the linear increase of the vertical stress with the embankment height (i.e. $\gamma H, \gamma$ is the soil unit weight and $H$ is the embankment height). In other words, no soil arching occurred. This is also an indication that soil arching across ss 2 started to form after the embankment height reached $100 \mathrm{~mm}$. Therefore, the height to clear spacing ratio, $h /(s-a)$, for the initiation of soil arching across ss 2 was 0.50 . Tensioned membrane and

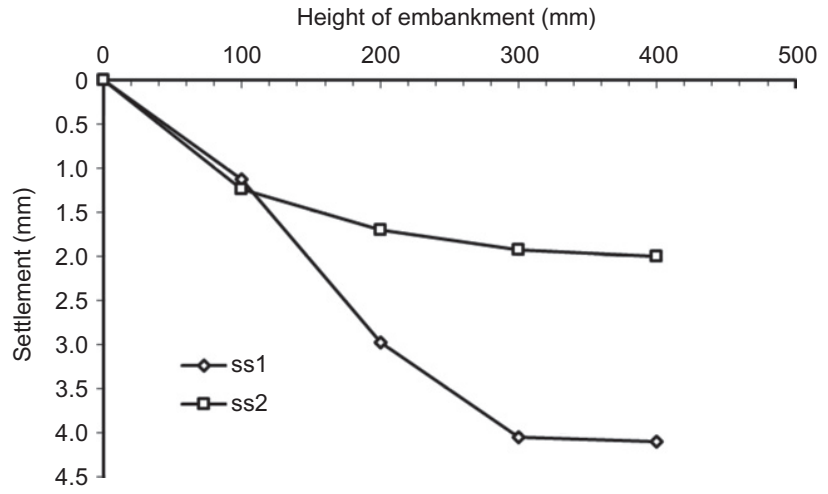

(a)

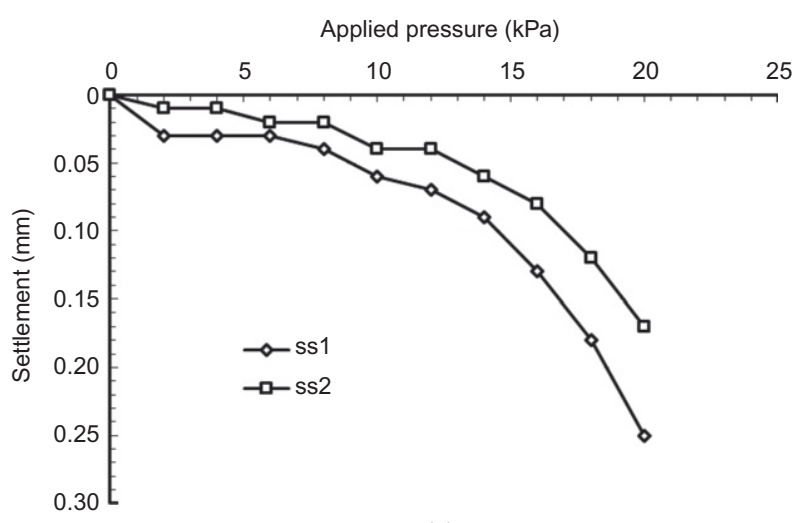

(b)

Figure 8. Measured settlements at the base of the embankment in model test 1: (a) during construction, (b) during loading

increase of subsoil modulus might have some effects on the reduction of the settlement rate, but these effects should be minor because the settlement at the embankment height of $100 \mathrm{~mm}$ was only $1.2 \mathrm{~mm}$. As Giroud and Noiray (1981) pointed out, the tensioned membrane effect became important only if the differential settlement was large. However, soil arching across ss1 started to form after the embankment height reached $200 \mathrm{~mm}$. Therefore, the height to clear spacing ratio, $h /\left(s^{\prime}-a^{\prime}\right)\left(s^{\prime}\right.$ is the diagonal centre-to-centre spacing between the piles and $a^{\prime}$ is the diagonal length of the pile cap), across ss1 was 0.71 . At the embankment height of $300 \mathrm{~mm}$, the settlements almost stopped increasing at both locations. This is the indication that full soil arching formed at the height to clear spacing ratios of 1.07 at ss 1 and 1.50 at ss2, respectively. The embankment height corresponding to the mobilisation of full soil arching is often referred to as the critical height in the literature (Han 2015a). These ratios are close to the value (1.3) suggested by Han and Gabr (2002) based on numerical analysis and the value (1.1 to 1.5$)$ by Chen et al. (2010) based on field test data.

\subsection{Influence factors}

Several factors influence the performance of GRPS embankments as demonstrated by Han and Gabr (2002). This study investigated the influences of the following factors: the cohesion of embankment fill, the type of pile, and the clear spacing between the pile caps. 


\subsubsection{Cohesion of embankment fill}

Model tests 1 and 2 were almost identical except for the properties of the embankment fill. Model test 1 used sand while model test 2 used a mixture of sand and fibres. As aforementioned, the sand-fibre mixture had an apparent cohesion of $15 \mathrm{kPa}$. The effect of the fill apparent cohesion on the performance of GRPS embankments is the focus of this section.

Vertical earth pressure and pile efficacy

Figure 9 shows the vertical earth pressures measured by epc2, epc3, epc4, and epc5 during the embankment construction and the loading process. For both embankment fills, the earth pressures measured by epc 2 to epc5 increased with the height of the embankment. When the embankment height was greater than $100 \mathrm{~mm}$, the earth pressures measured by epc 2 and epc 3 in test 2 were lower than that in test 1 . However, the earth pressures above the pile caps in test 2 were higher than those in test 1 . For both embankment fills, the earth pressures measured by epc5 were higher than those by epc4 after the embankment height was greater than $100 \mathrm{~mm}$. At the end of the embankment construction, the ratio of the embankment height $(h)$ to the clear spacing of pile caps $(s-a)$ was 2.0 in both tests 1 and 2, which meets the condition of full arching according to BS8006 (BSI 2010). The above test results indicate that the fill cohesion enhanced the soil arching and helped transfer more load from the subsoil to the pile caps. The measured earth pressures at the edge of the pile caps in both model tests were higher than those in

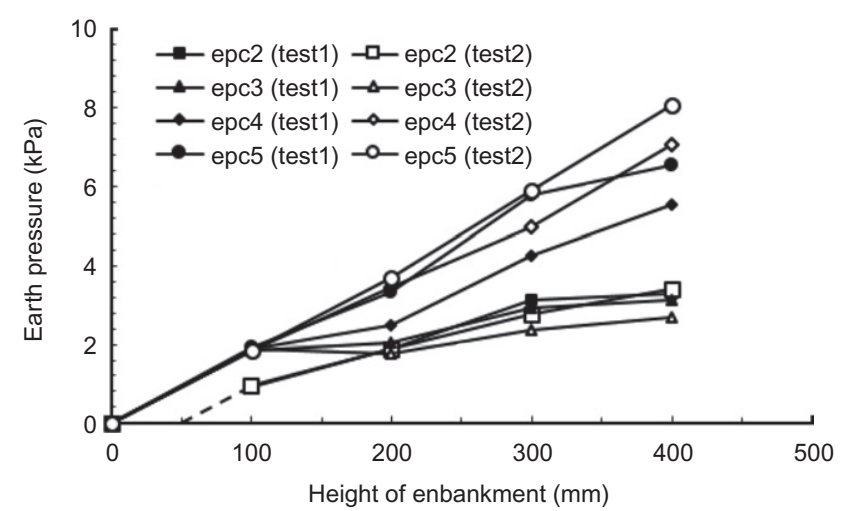

(a)

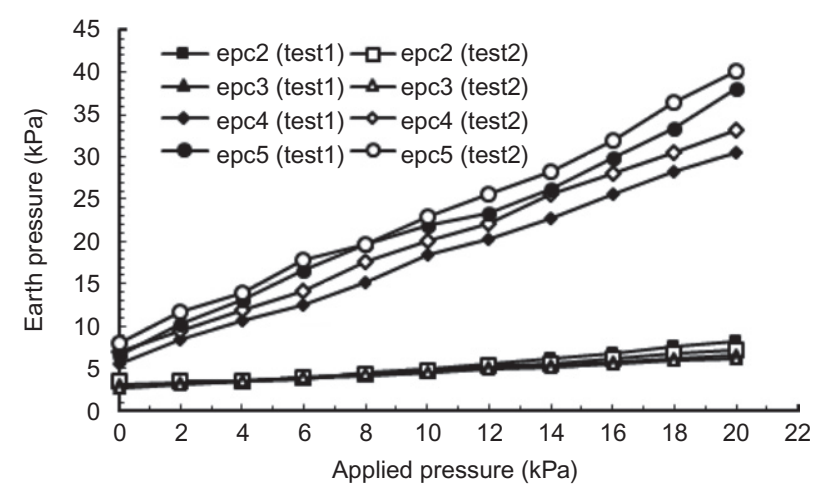

(b)

Figure 9. Measured earth pressures in model tests 1 and 2: (a) during construction, (b) during loading the centre of the pile caps. This result was in agreement with that obtained by Han and Gabr (2002) using the numerical method.

To further investigate the effect of the fill cohesion on the load distribution, $E_{\mathrm{p}}$ was calculated using Equation 1 based on the measured earth pressures in tests 1 and 2 . Figure 10 presents the relationships between the pile efficacy with the embankment height and the applied pressure on the crest of the embankment.

Figure 10a shows that for both embankment fills, $E_{\mathrm{p}}$ increased with the embankment height and was greater than $36 \%$ when the embankment height was more than $100 \mathrm{~mm}$. This result indicates that soil arching started to form after the embankment height exceeded $100 \mathrm{~mm}$, and more load was transferred to the pile caps by the soil arching effect with an increase of the embankment height. In addition, $E_{\mathrm{p}}$ in test 2 became greater than that in test 1. At the end of the embankment construction, $E_{\mathrm{p}}$ in test 2 was $61 \%$ whereas in test $1 E_{\mathrm{p}}$ was $52 \%$. The above results can be explained that the cohesion of the embankment fill in model test 2 increased the stiffness of the embankment fill and enhanced more load transfer from the subsoil to the pile caps.

Figure $10 \mathrm{~b}$ shows that the pile efficacy, $E_{\mathrm{p}}$, increased gradually with the applied pressure on the crest of the embankment for both embankment fills. However, $E_{\mathrm{p}}$ in

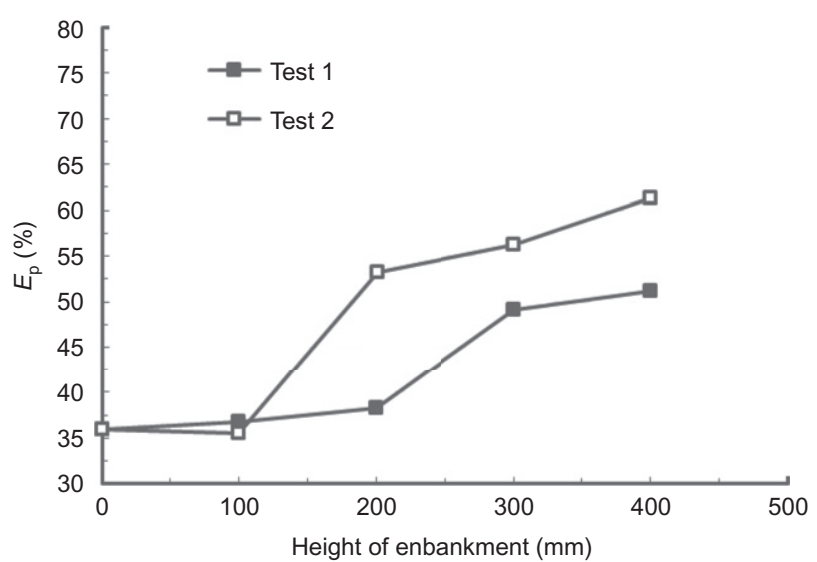

(a)

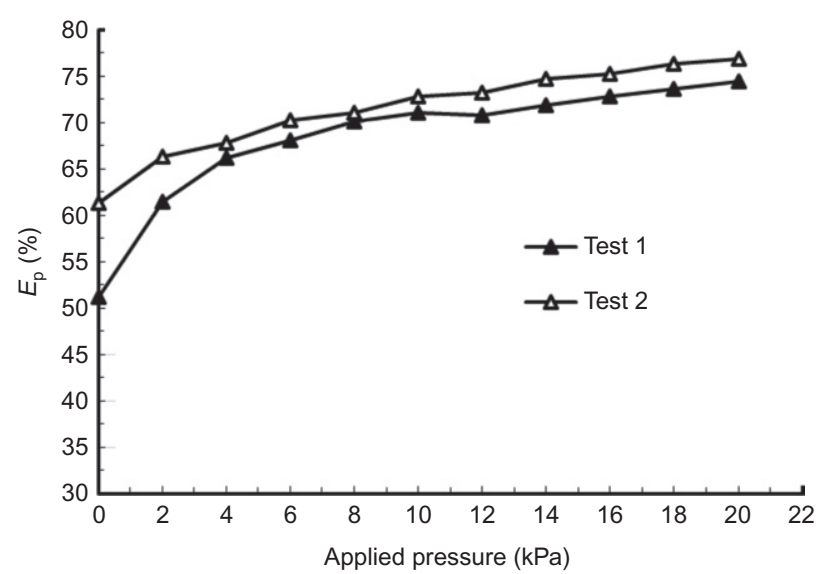

(b)

Figure 10. Calculated pile efficacies for model tests 1 and 2: (a) during construction, (b) during loading 
test 2 was slightly greater than that in test 1 under the applied pressure. The test results also show that the measured pressure on the subsoil by epc 2 and epc 3 increased with the fill height during the embankment construction and with the increase of the applied pressure on the crest of the embankment even though the end bearing piles were used.

\section{Settlements}

Figure 11 shows the settlements measured by ss1 and ss2 during the embankment construction and loading. In both tests, the measured settlements increased at a reduced rate when the embankment height was greater than $100 \mathrm{~mm}$, except that at ss 1 in model test 1 . This result indicates that soil arching started to form at the embankment height of $100 \mathrm{~mm}$. The measured settlements in test 1 were larger than those in test 2 because the cohesion in test 2 increased the stiffness of the fill and reduced the settlements. In both tests, the settlement at ss1 was larger than that at ss2. This is because ss 1 is at the centre of four adjacent pile caps whereas ss 2 is in the middle between two adjacent pile caps. The reason for soil arching starting to form at ss 1 earlier in test 2 than that in test 1 is that the fill cohesion enhanced soil arching.

Figure $11 \mathrm{~b}$ shows that the measured settlements at ss 1 and ss 2 increased with the applied pressure. The settlement increased at an accelerated rate when the applied pressure was higher than $12 \mathrm{kPa}$ in test 1 , while it happened at $16 \mathrm{kPa}$ in test 2 . This result can be explained by the fact that the fill cohesion in test 2 reduced the
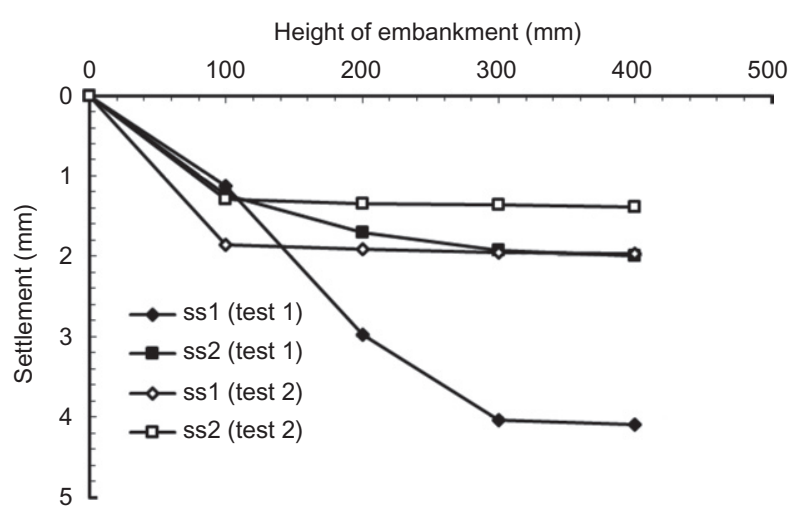

(a)

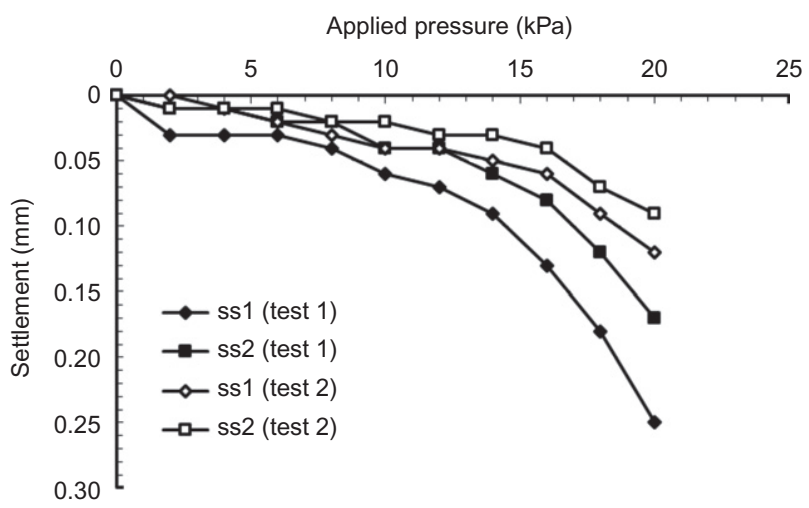

(b)

Figure 11. Measured settlements at the bases of the embankments in model tests 1 and 2: (a) during construction, (b) during loading vertical stress applied on the geosynthetic reinforcement and the subsoil.

As the pressure on the crest of the embankment was applied by the loading plate, the measured settlements of $\mathrm{S} 1$ and $\mathrm{S} 2$ were almost the same and their average value denoted as $S$ was calculated for each test. Figure 12 illustrates that the average settlement on the crest of the embankment increased with the applied pressure in both tests. The embankment in test 2 had much smaller settlements than that in test 1 because the fill cohesion in test 2 helped transfer more load to the piles.

The above test results and discussion demonstrate the cohesion of the embankment fill had an important role in enhancing soil arching, reducing the critical height, transferring more load to piles, and reducing the load transferred to the geosynthetic reinforcement and the subsoil. In some field projects, embankment fill is mixed with a hardening agent, such as lime, to gain cohesion. Ignoring fill cohesion will underestimate the load shared by piles but overestimate the load taken by the geosynthetic reinforcement and the subsoil and the settlement of the embankment. If the cohesion of the embankment fill exists for a long time, it should be taken into account during the design.

\subsubsection{Clear spacing of pile caps}

Model tests 2, 3, and 4 were almost identical except for the size of the pile caps. The size of the pile caps is expected to affect the critical height and the performance of the embankment. When a $300 \mathrm{~mm} \times 300 \mathrm{~mm}$ pile cap was placed at the centre-to-centre spacing of $500 \mathrm{~mm}$, the cap coverage area ratio of $300^{2} / 500^{2}=0.36$, which is close to the upper limit (0.4) as Han and Gabr (2002) found from field projects.

\section{Vertical earth pressure}

Figure 13 shows the vertical earth pressures measured by epc2, epc 3 and the calculated average pressure of epc 4 and epc5 during the embankment construction and loading. In Figure 13a, the earth pressures measured by epc2, epc3 and the calculated average pressure of epc4 and epc5 increased with the embankment height in all three tests. In test 3 , the earth pressure measured by epc 2 increased approximately linearly with the embankment

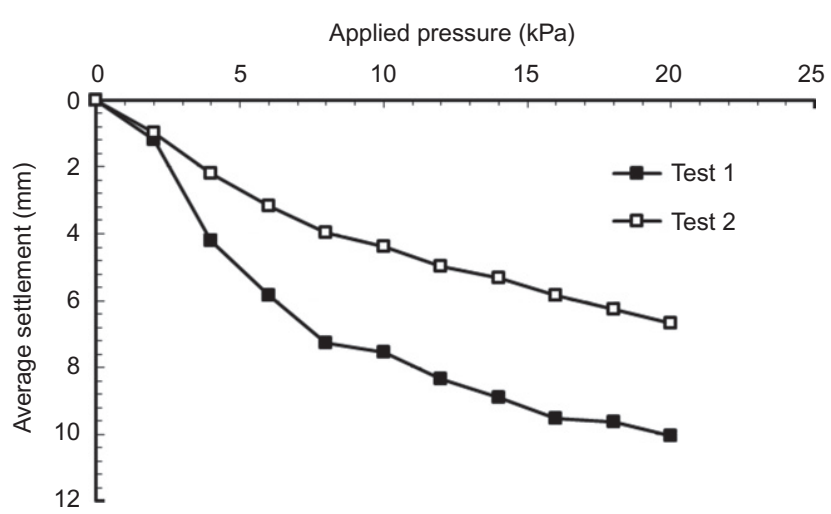

Figure 12. Measured settlements on the crests of the embankments in model tests 1 and 2 


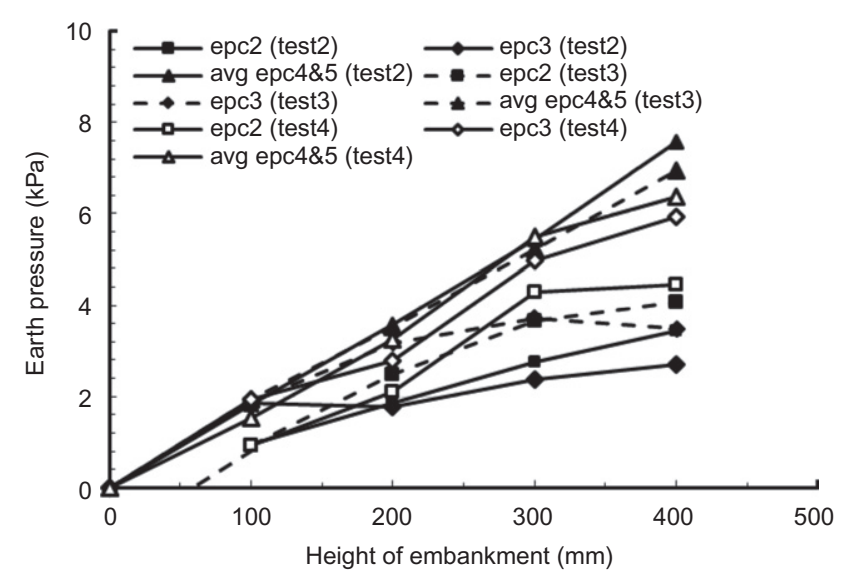

(a)

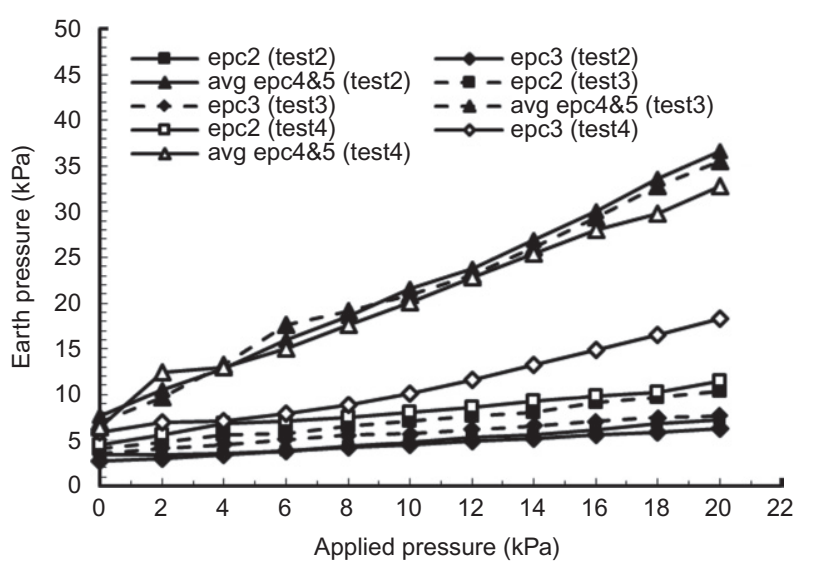

(b)

Figure 13. Vertical earth pressures in model tests 2, 3, and 4: (a) during construction, (b) during loading

height until the embankment height of $300 \mathrm{~mm}$, then increased at a reduced rate, whereas the earth pressure measured by epc3 increased approximately linearly with the embankment height until the height reached $100 \mathrm{~mm}$ and then increased at a reduced rate. This result indicates that soil arching started to form at the embankment height of $100 \mathrm{~mm}$ and more load transferred to the pile caps. At this embankment height, the ratio of the embankment height to the clear spacing of pile caps, $h /(s-a)$, was 0.50 . In test 3 , the earth pressure measured by epc 3 increased approximately linearly with the embankment height until the embankment height was $200 \mathrm{~mm}$, and then increased at a reduced rate. This result indicates that soil arching started to form at the embankment height of $200 \mathrm{~mm}$ and more load transferred to the pile caps. At this embankment height, the ratio of the embankment height to the clear spacing of pile caps, $h /(s-a)$, was 0.5 . In test 4 , even though the earth pressure between the pile caps measured by epc 3 was lower than that above the pile caps, it increased nearly linearly with the embankment height up to $400 \mathrm{~mm}$. This height corresponds to a $h /(s-a)$ ratio of 1.1. This result indicates no soil arching formed in this embankment.

In Figure 13b, with an increase of the applied pressure on the crest of the embankment, the measured earth pressures increased approximately linearly regardless of

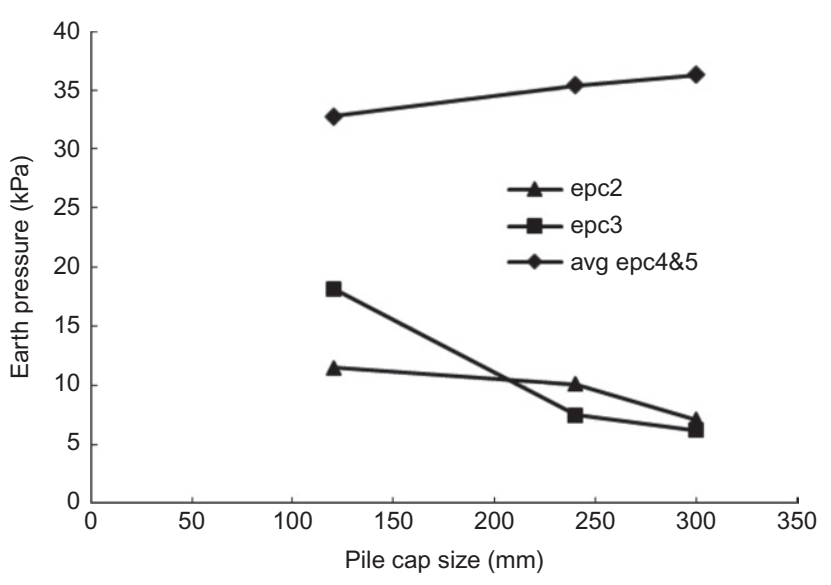

Figure 14. Earth pressure variations with pile cap size in model tests 2,3 and 4

the clear spacing of the pile caps. However, the earth pressures between the pile caps in tests 2 and 3 increased slowly in comparison with that in test 4 . This difference resulted from different levels of soil arching mobilised in the embankments.

Figure 14 shows the vertical earth pressure variations with the pile cap size at the applied pressure of $20 \mathrm{kPa}$. With an increase of the pile cap size, the measured earth pressures of epc 2 and epc 3 decreased and the average pressure of epc 4 and epc 5 increased. It can be concluded that the soil arching effect increased with as the pile cap size increased (it is also true with a decrease of clear spacing of pile caps).

\section{Settlements}

Figure 15 shows the measured settlements at ss1 and ss2 in tests 2, 3, and 4 during the embankment construction and loading. The settlements at ss 1 and ss 2 increased with the embankment height but the rate of settlement significantly decreased after the embankment height exceeded $100 \mathrm{~mm}$. The reduction of the settlement rate could result from soil arching and tensioned membrane effects. As discussed earlier, the tensioned membrane effect becomes important when the differential settlement between pile caps become large. The embankment with a smaller $h /(s-a)$ ratio had a higher settlement between the pile caps. This result can be attributed to less soil arching and tensioned membrane effects at a smaller $h /(s-a)$ ratio but higher earth pressures on the subsoil as shown in Figure 13a.

Figure $15 \mathrm{~b}$ shows that the measured settlements at ss 1 and ss 2 increased with the applied pressure on the crest of the embankment. The result indicates that the subsoil between the pile caps settled during loading at different $h /(s-a)$ ratios. Even when the $h /(s-a)$ ratio was 2.0 , not all the applied pressure transferred to the pile caps. In these three model tests, the settlements between the pile caps differed. More significantly the settlement at ss 2 in test 4 was 3.6 times that in test 2. This result further indicates large clear spacing between the pile caps minimised soil arching and tensioned membrane effects and transferred more load to the subsoil. 


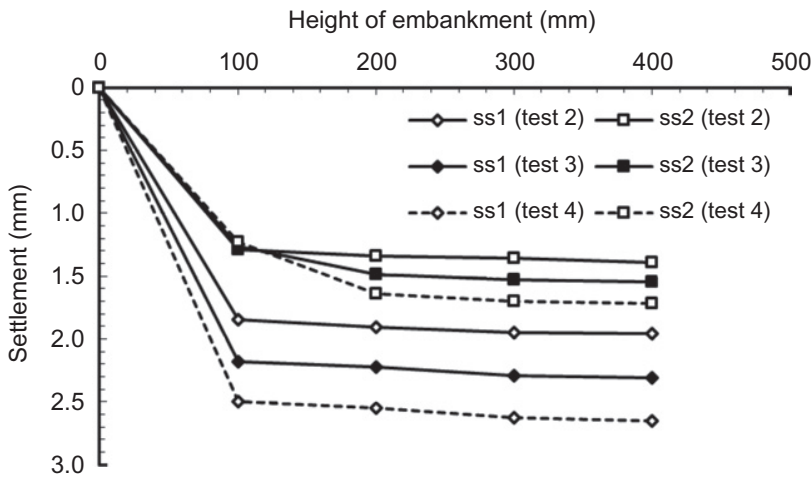

(a)

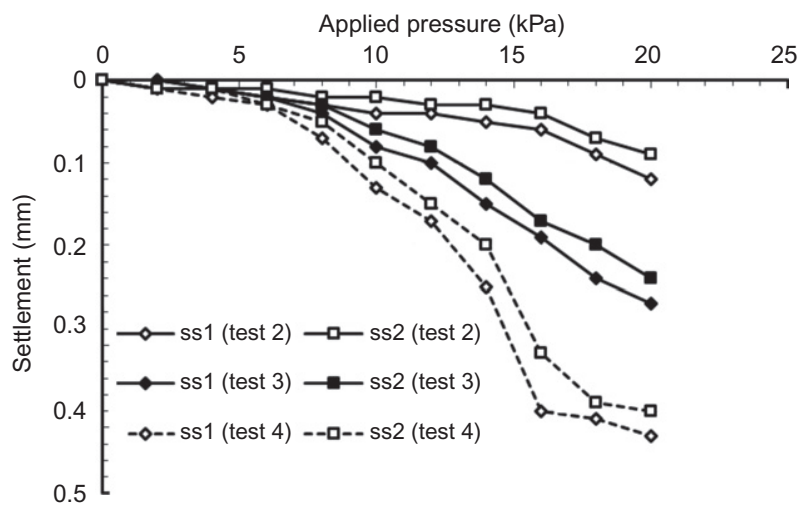

(b)

Figure 15. Measured settlements at the bases of embankments in model tests 2, 3, and 4: (a) during construction, (b) during loading

\subsubsection{Pile type}

Tests 2 and 5 or tests 3 and 6 were almost identical except for the pile type. Model tests 2 and 3 used end-bearing piles whereas model tests 5 and 6 had floating piles. As the comparative results of tests 3 and 6 were similar to those of tests 2 and 5, only the comparative results of tests 2 and 5 are presented herein.

Vertical earth pressure and pile efficacy

Figure 16 shows the vertical earth pressures measured by epc2, epc3, epc4, and epc5 during the embankment construction and loading. During the embankment construction, the measured earth pressures in tests 2 and 5 increased with the embankment height. Figure 16a shows that the rate of vertical earth pressure increase between the pile caps decreased when the embankment height was greater than $100 \mathrm{~mm}$. This reduced rate indicates that the soil arching effect took place. The earth pressures measured by epc 4 and epc 5 in test 2 with end-bearing piles were slightly higher than those in test 5 with floating piles. The earth pressure at the edge of the pile cap (ep5) in either test 2 or test 5 was higher than that in the centre of the pile cap (ep4). This result is in agreement with that obtained by Han and Gabr (2002). In addition, the measured pressures on the pile cap in test 2 were higher than those in test 5 because end-bearing piles had a stiffer response than floating piles and more load transferred to end-bearing piles.

Figure 16b shows the measured vertical earth pressures during loading on the crest of the embankment. Even though all the measured vertical earth pressures in both

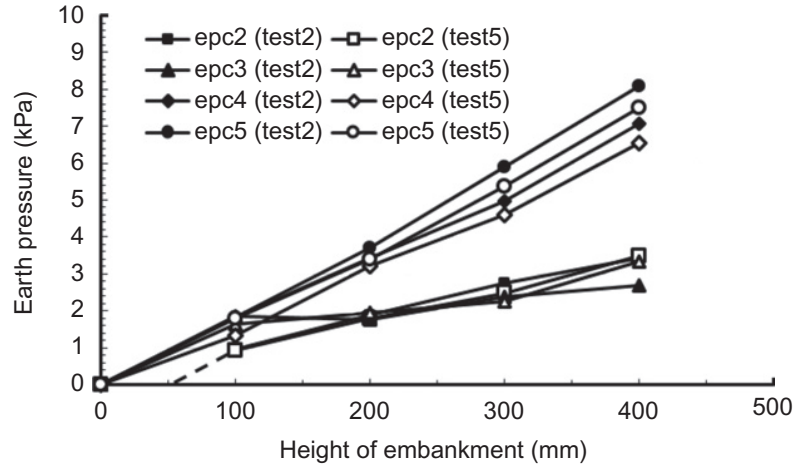

(a)

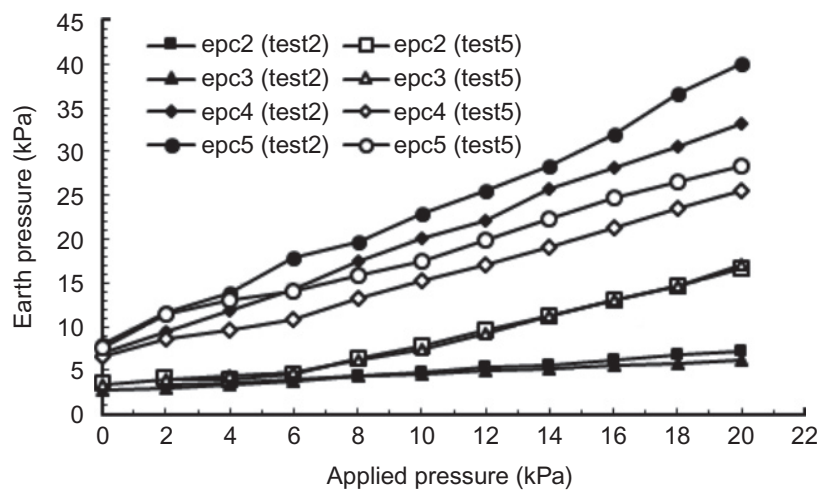

(b)

Figure 16. Measured vertical earth pressures in model tests 2 and 5: (a) during construction, (b) during loading

tests increased with the applied pressure, the patterns of load increase in tests 2 and 5 are different. In test 2, the difference in the earth pressures by epc3 and epc4 increased with the applied pressure. In test 5 , however, the four measured earth pressures increased parallel with each other after the applied pressure exceeded $6 \mathrm{kPa}$. At the end of tests 2 and 5 , the earth pressures above the pile caps in test 2 were much higher than those in test 5; however, the earth pressures between the pile caps in test 2 were lower than those in test 5 . This result indicates that end-bearing piles carried more load than floating piles through soil arching and tensioned membrane effects.

Figure 17 shows the calculated pile efficacies in both model tests during the embankment construction and loading. Figure $17 \mathrm{a}$ indicates $E_{\mathrm{p}}$ in tests 2 and 5 increased with the embankment height in a similar manner. The difference in $E_{\mathrm{p}}$ by the end-bearing piles and the floating piles was minor during the embankment construction. This result is consistent with that result of the measured earth pressures as shown in Figure 16a.

Figure $17 \mathrm{~b}$ shows that $E_{\mathrm{p}}$ in test 5 decreased after the applied pressure exceeded $6 \mathrm{kPa}$, while $E_{\mathrm{p}}$ in test 2 increased with the applied pressure. The reduction of pile efficacy in test 5 resulted from the movement of the floating pile when the applied pressure was higher than $6 \mathrm{kPa}$. The movement or settlement of the floating pile minimised soil arching formed during the embankment construction; therefore, partial load transferred to the geosynthetic reinforcement between piles, which was resisted by the subsoil. 


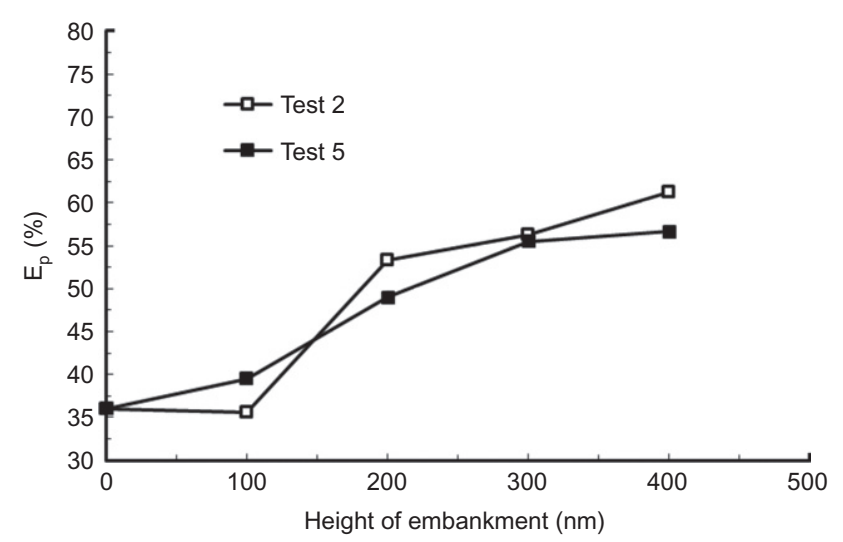

(a)

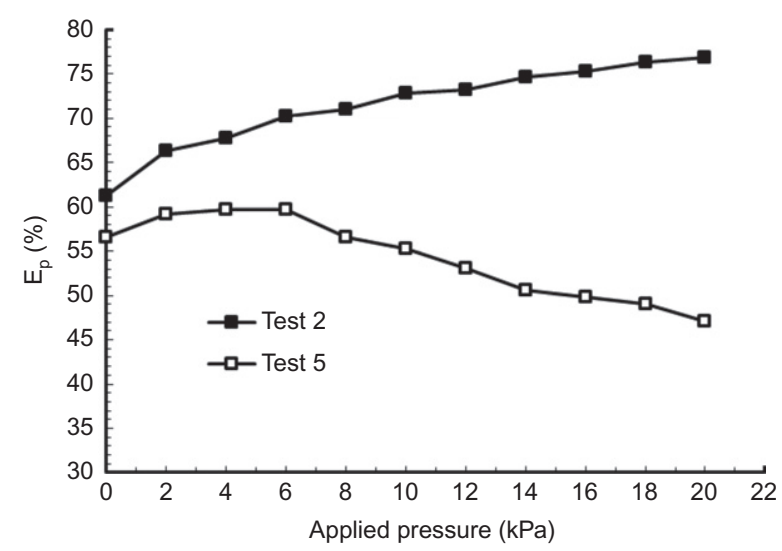

(b)

Figure 17. Calculated pile efficacies for model tests 2 and 5: (a) during construction, (b) during loading

\section{Settlements}

Figure 18 shows the measured settlements at ss1, ss2, and sp1 in tests 2 and 5. During the embankment construction, the settlements at ss1, ss2, and sp1 increased with the embankment height. The settlement of the pile cap (i.e. at sp1) on the end-bearing pile in test 2 was nearly zero and therefore is not reported. However, the settlement at sp1 in test 5 was also small but detectable due to the movement of the floating pile.

Figure 18b shows that the settlements of the subsoil increased with the applied pressure, while the settlements in test 5 were larger than those in test 2 . The large settlement in test 5 also resulted from the movement of the floating piles under the applied pressure.

Figure 19 shows that the average settlement on the crest of the embankment increased with the applied pressure for both tests. The average settlement on the crest of the embankment in test 2 was smaller than that in test 5 . This is further evidence that the pile type affected soil arching and load transfer.

The above discussion leads to the conclusion that when floating piles are used in GRPS embankments, an increase of the embankment height increases the load on the piles, the piles begin to settle, and then the distribution of the load on the piles, the geosynthetic reinforcement, and the subsoil changes due to soil arching and tensioned membrane effects and subsoil support.

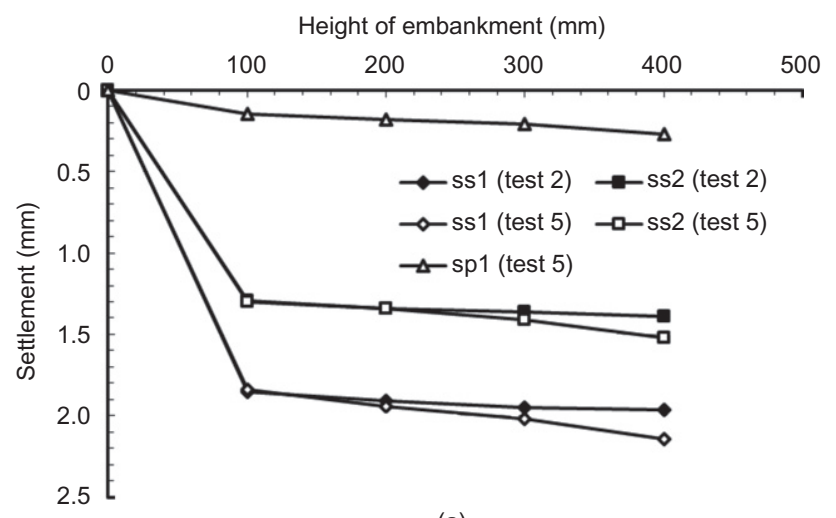

(a)

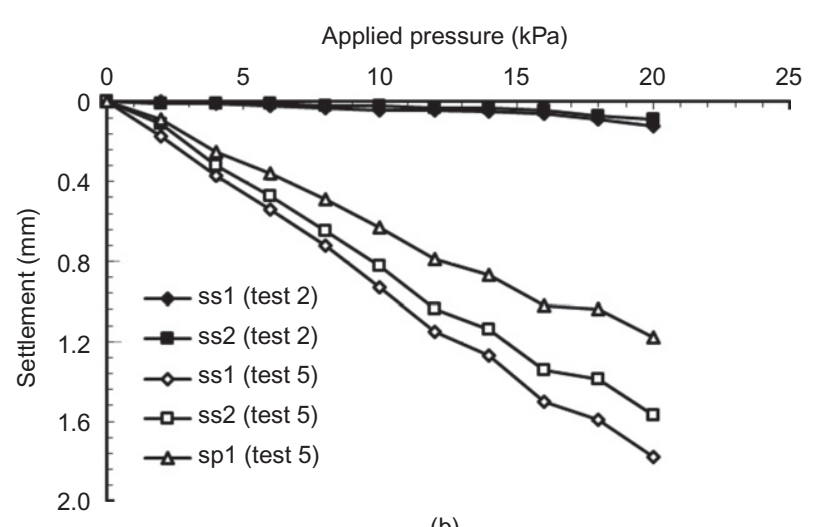

(b)

Figure 18. Measured settlements at the bases of embankments in model tests 2 and 5: (a) during construction, (b) during loading

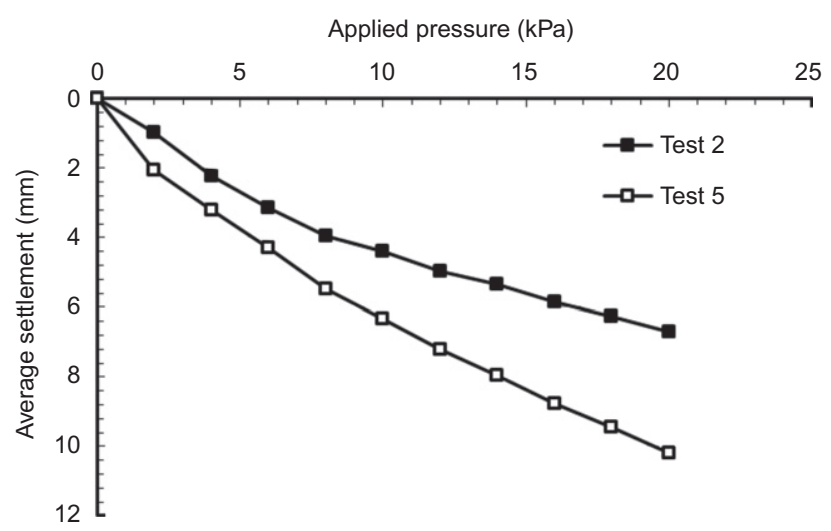

Figure 19. Measured average settlements on the crests of embankments in model tests 2 and 5

\section{CONCLUSIONS}

Six scaled model tests were conducted in this study to investigate the influence of the cohesion of the embankment fill, the type of piles, and the clear spacing of pile caps on the performance of GRPS embankments. The following conclusions can be drawn from the model test results and above discussions.

(1) The cohesion of the embankment fill had a significant influence on soil arching, which distributed more loads from the weight of the embankment and the applied pressure to the piles. The embankment 
fill with cohesion resulted in a larger pile efficacy and smaller settlements of the subsoil between the pile caps and on the crest of the embankment than that without cohesion.

(2) Floating piles could be used to support GRPS embankments as end-bearing piles. With an increase of the applied pressure on the crest of the embankment, the floating piles began to settle thus resulting in re-distribution of the applied load among the pile caps, the geosynthetic reinforcement, and the subsoil. Floating piles resulted in less soil arching, because the stiffness difference between the piles and their surrounding soil was less than that for end-bearing piles. As a result, the load on the floating piles was lower and the load on the subsoil was higher. The embankment on the floating piles had a larger settlement than that on the end-bearing piles.

(3) Test results show that soil arching started to form at the ratio of the embankment height to the clear spacing of pile caps at 0.5 to 0.7 . The critical height for full soil arching was at 1.1 to 1.5 times the clear spacing of pile caps.

(4) Regardless of fill cohesion, pile type, and the clear spacing of pile caps, the vertical earth pressure on the edge of the pile cap was higher than that in the centre.

\section{ACKNOWLEDGEMENTS}

The authors would like to acknowledge the Natural Science Foundation of China for its financial support for this study through the grants No. 41272293 and No. 51478149.

\section{NOTATION}

Basic SI units are given in parentheses.

$a$ the width of a pile cap (m)

$a^{\prime}$ the diagonal length of a pile cap (m)

$E_{\mathrm{p}}$ the pile efficacy (dimensionless)

$\mathrm{ep}_{2}$ the vertical earth pressure measured by pressure cell epc2 $(\mathrm{Pa})$

$\mathrm{ep}_{3}$ the vertical earth pressure measured by pressure cell epc3 $(\mathrm{Pa})$

$\mathrm{ep}_{4}$ the vertical earth pressure measured by epc4 $(\mathrm{Pa})$

$\mathrm{ep}_{5}$ the vertical earth pressure measured by epc5 (Pa)

$h$ the embankment height (m)

$s$ the centre-to-centre spacing of piles (m)

$s^{\prime} \quad$ the diagonal centre-to-centre spacing between piles (m)

\section{REFERENCES}

ASTM D2487-11 Standard Practice for Classification of Soil for Engineering Purpose (Unified Soil Classification System). ASTM International, West Conshohocken, PA, USA.

BSI (British Standard Institute) (2010). British Standard 8006: Strengthened/Reinforced Soils and Other Fills, British Standard Institution, London, UK.
Chen, R. P., Chen, Y. M., Han, J. \& Xu, Z. Z. (2008a). A theoretical solution for pile-supported embankments on soft soil. Canadian Geotechnical Journal, 45, No. 5, 611-623.

Chen, R. P., Xu, Z. Z., Chen, Y. M., Ling, D. S. \& Zhu, B. (2010). Field tests of pile-supported embankments over soft ground. Journal of Geotechnical and Geoenvironmental Engineering, 136, No. 6, 777-785.

Chen, Y. M., Cao, W. P. \& Chen, R. P. (2008b). An experimental investigation of soil arching within basal reinforced and unreinforced piled embankments. Geotextiles and Geomembranes, 26 , No. 2, 164-174.

EBGEO (2010). Recommendations for Design and Analysis of Earth Structures using Geosynthetic Reinforcements -EBGEO, EBGEO.

El Kamash, W. \& Han, J. (2014). Displacements of column-supported embankments over soft clay after widening considering soil consolidation and column layout: numerical analysis. Soils and Foundations, 54, No. 6, 1054-1069.

Ellis, E. \& Aslam, R. (2009a). Arching in piled embankments. Comparison of centrifuge tests and predictive methods, Part 1 of 2. Ground Engineering, 42, No. 6, 34-38.

Ellis, E. \& Aslam, R. (2009b). Arching in piled embankments. Comparison of centrifuge tests and predictive methods, Part 2 of 2. Ground Engineering, 42, No. 6, 28-31.

Farag, G. S. F. (2008). Lateral spreading in basal reinforced embankments supported by pile-like elements, Halvordson, K. A., Plaut, R. H. \& Filz, G. M., Editors, Schiftenreihe Getechnik (20) Kassel university press GmbH, März, Germany, 182 p.

Giroud, J. P. \& Noiray, L. (1981). Geotextiles-reinforced unpaved road design. ASCE, Journal of Geotechnical Engineering, 107, No. 9, 1233-1253.

Han, J. (1999). Design and construction of embankments on geosynthetic reinforced platforms supported by piles. Invited Speaker, ASCE/PaDOT Geotechnical Seminar, Hershey, PA, Apr. 14-16.

Han, J. (2015a). Principles and Practice of Ground Improvement, John Wiley \& Sons, Hoboken, New Jersey, USA, ISBN: 978-1118-25991-7, June, 432p.

Han, J. (2015b). Recent research and development of ground column technologies. Proceedings of the Institution of Civil Engineers Ground Improvement, 168, No. 4, 246-264, http://dx.doi.org/ 10.1680/grim.13.00016.

Han, J. \& Gabr, M. A. (2002). Numerical analysis of geosyntheticreinforced and pile-supported earth platforms over soft soil. Journal of Geotechnical and Geoenvironmental Engineering, 128, No. 1, $44-53$.

Han, J., Oztoprak, S., Parsons, R. L. \& Huang, J. (2007). Numerical analysis of foundation columns to support widening of embankments. Computers and Geotechnics, 34, No. 6, 435-448.

Heitz, C. (2006). Bodengewölbe unter ruhender und nichtruhender Belastung bei Berücksichtigung von Bewehrungseinlagen aus Geogittern, Schriftenreihe Geotechnik, Universität Kassel, März, Kassel, Germany (19) (in German).

Hewlett, W. J. \& Randolph, M. F. (1988). Analysis of piled embankments. Ground Engineering, 22, No. 3, 12-18.

Horgan, G. J. \& Sarsby, R. W. (2002). The arching effect of soils over voids and piles incorporating geosynthetic reinforcement. Geosynthetics, Delmas, Ph., Gourc, J. P. \& Girard, H., Editors, 7th ICG Delmas, Nice, France, pp. 373-378.

Huang, J., Han, J. \& Collin, J. G. (2005). Geogrid-reinforced pile-supported railway embankments - A three dimensional numerical analysis. Journal of Transportation Research Board, 1936, 221-229.

Jenck, O., Dias, D. \& Kastner, R. (2007). Two-dimensional physical and numerical modeling of a pile-supported earth platform over soft soil. Journal of Geotechnical and Geoenvironmental Engineering, 133, No. 3, 295-305.

Jenck, O., Dias, D. \& Kastner, R. (2009). Discrete element modelling of a granular platform supported by piles in soft soil validation on a small scale model test and comparison to a numerical analysis in a continuum. Computers and Geotechnics, 36, No. 6, 917-927. 
Le Hello, B. (2007). Renforcement par geosynthetiques des remblais sur inclusions rigides, étude expérimentale en vraie grandeur et analyse numérique, $\mathrm{PhD}$ thèses, l'université Grenoble I, France (in French).

Low, B. K., Tang, S. K. \& Chao, V. (1994). Arching in piled embankments. Journal of Geotechnical and Geoenvironmental Engineering, ASCE, 120, No. 11, 1917-1938.

Miao, L., Wang, F., Han, J. \& Lv, W. (2014). Benefits of geosynthetic reinforcement in embankment widening subjected to foundation differential settlement. Geosynthetics International, 21, No. 5, 321-332.

Miao, L. C., Wang, F., Han, J., Lv, W. H. \& Li, J. (2013). Properties and applications of cement-treated sand-expanded polystyrene bead lightweight fill. ASCE Journal of Materials in Civil Engineering, 25, No. 1, 86-93.

Sowers, G. F. (1979). Introductory Soil Mechanics and Foundations: Geotechnical Engineering, 4th edition, Macmillan Publishing Co., New York, USA. van Eekelen, S. J. M. (2015). Basal Reinforced Piled Embankments: Experiments, Field Studies and the Development and Validation of A New Analytical Design Model, PhD dissertation, TU, Delft, the Netherlands.

van Eekelen, S. J. M., Bezuijen, A. \& Oung, O. (2003). Arching in piled embankments; experiments and design calculations. Proceedings of ICOF Conference, Dundee, Scotland, September 2003, 885-894.

van Eekelen, S. J. M., Bezuijen, A., Lodder, H. J. \& van Tol, A. F. (2012). Model experiments on piled embankments. Part I. Geotextiles and Geomembranes, 32, 69-81.

van Eekelen, S. J. M., Bezuijen, A. \& van Tol, A. F. (2013). An analytical model for arching in piled embankments. Geotextiles and Geomembranes, 39, 78-102.

Zaeske, D. (2001). Zur Wirkungsweise von unbewehrten und bewehrten mineralischen Tragschichten über pfahlartigen Gründungselementen, Schrif- tenreihe Geotechnik, Uni Kassel, Kassel, März, Kassel, Germany (10) (in German).

The Editor welcomes discussion on all papers published in Geosynthetics International. Please email your contribution to discussion@geosynthetics-international.com by 15 October 2016. 